\begin{abstract}
Great Britain has had statutory regulation of minimum pay for much of this century but never previously had a national minimum wage (NMW). This paper outlines the history of minimum wage regulation culminating in 1997 with the establishment of the Low Pay Commission (LPC) and the introduction of the NMW this year. The main issues considered by the LPC were the definition of the NMW, the rate itself and what to do about younger workers. As well as its own deliberations, the LPC took written and oral evidence and held over 200 meetings around the United Kingdom. This process was vital in achieving unanimity around a NMW ( $£ 3.60$ from April 1999 for those aged 22+) acceptable to the government. Comparative international evidence on coverage and cost was also important in coming to our conclusions and the British NMW is towards the middle of the range of coverage among OECD countries. Although there is general agreement that minimum wage systems reduce wage inequality, their impact on the distribution of household income is more controversial. Evidence presented suggests the NMW may have a more egalitarian impact on household incomes than is sometimes asserted. The Report of the LPC is only the beginning of the story. Responses to it were generally favourable: parliamentary regulations are needed to translate the recommendations into law; the NMW has to be enforced and evaluated. This necessary follow-up to the Report is discussed in the concluding sections.
\end{abstract}

This paper was produced as part of the Centre's Industrial Relations Programme 
The British National Minimum Wage

David Metcalf

March 1999 
Series Editor: Graham Ingham

Published by

Centre for Economic Performance

London School of Economics and Political Science

Houghton Street

London WC2A 2AE

(C) David Metcalf, submitted February 1999

ISBN 0753012693

Individual Copy price: $£ 5$ 


\section{The British National Minimum Wage}

\section{David Metcalf}

I. INSTITUTION AND PROCESSES 1

1. History of Minimum Wage Regulation 1

2. Low Pay Commission 2

II. MAIN DEBATES AND RECOMMENDATIONS 5

3. Definition of the NMW 5

4. Choice of NMW 6

5. Youths 7

6. Who Benefits from the NMW? 8

III. INTERNATIONAL CONTEXT AND DISTRIBUTIONAL IMPACT 9

7. International Evidence on Minimum Wage Systems 9

8. The Impact of the NMW on the Distribution of Household Income 10

IV. AFTER THE REPORT 12

9. Responses 12

10. Regulations 14

11. Enforcement 15

12. Monitoring and Evaluation 16

$\begin{array}{lr}\text { Tables } & 18\end{array}$

$\begin{array}{ll}\text { References } & 26\end{array}$

The Centre for Economic Performance is funded by the Economic and Social Research Council 


\section{Acknowledgements}

I am a member of the Low Pay Commission and have drawn freely on our first report (LPC, 1998) in preparing this article. I wish to acknowledge the contribution of my fellow Commissioners and the LPC Secretariat whose ideas and research are reported here. But I alone am responsible for matters of interpretation in this piece. I acknowledge, with thanks, advice, evidence and comments from Richard Dickens, Stephen Dunn, Sue Fernie, Paul Gregg, Amanda Gosling, Fleur W Ham, Kirstine Hansen, Stephen Machin, Alan Manning and anonymous referees and editors - especially Paul Marginson and Stephen Wood - of the British Journal of Industrial Relations. I have drawn on Bain (1999) in Section 1. There is a companion paper (Metcalf, 1999) which deals with issues of greater interest to economists. I am most grateful to the editor of the Economic Journal, Stephen Machin, for permission to draw on that paper in Sections 3-5. I also wish to thank participants at the British Universities Industrial Relations Associates, Keele University, 3 July 1998 and the Education and Employment Economics Group, DfEE, 31 October 1998 whose insights and comments have improved this paper. 


\section{The British National Minimum Wage}

\section{David Metcalf}

Statutory regulation of minimum pay has existed for most of this century in the United Kingdom but there has never previously been a national minimum wage (NMW). From April 1999 there is a NMW of $£ 3.60$ an hour for those aged $22+$ with a lower rate of $£ 3$ for those aged 18-21. This paper is organised in four parts. Part I deals with institutions and processes. A brief history of minimum wage regulation is presented in Section 1, followed in Section 2 by a discussion of the operation of the Low Pay Commission (LPC) which recommended the NMW. The three main debates inside the LPC are the subject of Part II and concerned the definition of the NMW, the choice of the rate itself and how to treat younger workers. These debates are discussed in Sections 3-5 respectively. Evidence on the groups of workers who will gain from the introduction of the NMW is presented in Section 6. Part III examines international and domestic evidence on the impact of NMW systems. Most OECD countries have some system of minimum wages and the UK is put into a comparative context in Section 7. That section concludes that minimum wage systems reduce pay inequality, but any impact of the NMW on the distribution of household income is more controversial - some evidence for the UK is presented in Section 8.

Part IV sets out the reactions and follow up to the Report of the LPC, recommending the level of the NMW, published in June 1998 (LPC, 1998). Reactions to the Report are analysed in Section 9. The Report is only the beginning of the story. The Regulations by which the recommendations are translated into law are discussed in Section 10. The important matter of enforcement is examined in Section 11, and finally, implementation and evaluation of the NMW are considered in Section 12.

\section{INSTITUTION AND PROCESSES}

\section{History of Minimum Wage Regulation}

Great Britain has had statutory regulation of some wages for almost all this century (see Metcalf, 1981, chapter 5). For example the Fair Wage Resolutions (FWR) were introduced in 1891 in an attempt to eliminate unfair competition for public sector contracts based on undercutting recognised pay rates. These FWRs were in place for ninety years. Similarly, the Wage Council system was established in 1909, peaked with a coverage of 3.5 million workers in 1953, and successfully provided surrogate collective bargaining for many low paid workers until the councils were all abolished in 1993.

Both the union movement and the Labour party supported the Wages Council system of setting minimum wages, and were generally, but not universally, hostile to a statutory NMW, because they aspired to replace the Councils by collective bargaining. But the advent of the Conservative government in 1979 stymied any such extension of collective bargaining. During the 1980s the Wage Councils" "bite" — their pay rates relative to average pay — weakened, under 21 year olds were removed from coverage and inspection and enforcement efforts ground to a halt. Led by Rodney Bickerstaffe from (as it was then) the National Union of Public Employees ably supported by Chris Pond from the Low Pay Unit pressure group - first the Trades Union Congress (in 1985) and then the Labour Party (in 1986) embraced the NMW. For the traditionalists in the union movement the embrace was not very warm. Even in the debate in 
which the TUC adopted the NMW Ron Todd, General Secretary of the Transport and General Workers' Union (TGWU) expressed the "fear that a statutory minimum could be used by employers to undermine trade union organisation, negotiation and collective bargaining" and as late as 1991 Gavin Laird of the Amalgamated Engineering and Electrical Union (AEEU) was arguing that "you can't advance free collective bargaining and at the same time advance the national minimum wage. The two things must be incompatible".

Much of the discussion among trade unions in the last decade has focused on the method of establishing the desirable level of the NMW. There was broad support for a formula based around half male median earnings, which was seen as a means of setting the rate at the level many in the union movement considered appropriate. It was also seen by some as a mechanism to provide automatic uprating of the NMW. Initially, the Labour Party supported the formulaic approach, but abandoned it in 1995 proposing instead the establishment of a Commission, which would recommend to the government a level for the initial rate. Two key factors led to this change of policy. First, a concern that a level of half male median earnings would have serious adverse economic effects (particularly if the idiosyncratic method of calculation favoured by the unions was adopted, see below). Second, a belief that it would be a political and economic mistake to allow the level of the minimum wage to be determined in a way which took no account of wider economic and social circumstances such as employment levels and income distribution.

Employer views have also changed over time. Although some remain opposed to the NMW, many others accept it in principle. For example, whereas in 1995 the CBI was arguing "that even a low minimum wage would reduce job opportunities and create major problems for wages structures in a wide range of companies", by the time it submitted evidence to the LPC in 1997 it had come to the view "that the appropriate and feasible purpose for the NMW is to create a 'floor' to the labour market". There are probably two major reasons for this alteration to the stance of employers. It surely reflects a pragmatic recognition that, since the Labour Party was firmly committed to introducing the NMW, the most appropriate tactic for employers was not to fight the principle but to seek to influence the level at which it was set. In addition, many employers are seized of recent research which demonstrates that an appropriately set NMW can protect them from undercutting without an adverse macroeconomic impact on employment and inflation (see eg LPC (1998) appendix 11).

\section{Low Pay Commission}

The LPC was established in July 1997. Its chair is George Bain, Vice Chancellor of Queens University. The nine Commissioners represent the interests of unions and employees, employers and the independent community but sit as individuals. Members are not delegates representing a group to whom they have to report back. The appointment process was one of the first under the new Nolan open government procedures. The civil service secretariat was deliberately kept small, fewer than a dozen professional employees plus associated support staff.

The Commission's original terms of reference were:

- To recommend the initial level at which the NMW might be introduced;

- To make recommendations on lower rates or exemptions for those aged 16-25.

These terms of reference were revised in November 1998. The LPC is now asked to:

- Monitor and evaluate the introduction and impact of the NMW;

- Review the position of 21 year olds... in particular whether they should be covered by the adult rate.

In making recommendations the LPC must "have regard to: wider economic and social implications; the likely effect on employment and inflation; the impact on competitiveness of business, particularly small firms; and the potential impact on costs to industry and the Exchequer". 
The unanimously agreed main recommendations of the LPC were:

- An NMW of $£ 3.60$ for those aged 21+ from April 1999;

- A development rate of $£ 3.20$ for those aged 18-20;

- The development rate of $£ 3.20$ also to be applied for a period of up to 6 months to those aged $21+$ who are on a bona fide training course.

There were a further 21 recommendations concerning, for example, the definition of earnings, treatment of apprenticeships, and compliance procedures. The following main groups are excluded from coverage: the self-employed, those aged 16 and 17 and those on apprenticeships. The government accepted the recommended adult rate. But it decided that the youth rate should be $£ 3.00$ (rising to $£ 3.20$ in 2000) and should apply to those aged 18-21 inclusive, rather than 1820 as the LPC recommended.

The process by which the LPC reached its recommendations had three strands: written and oral evidence, site visits and discussion and argument within the Commission. From the outset the LPC engaged in an open consultation process. Evidence was invited from nearly 600 employer organisations, trade associations, unions, voluntary organisations, pressure groups and academics. Written evidence was received from around 500 organisations and formal oral evidence was taken from 47 representative groups of employers, unions and pressure groups.

The LPC also visited 61 cities, towns and villages across the UK. These provided the opportunity to meet representative organisations and interested individuals at local level. The meetings - over 200 - were informal to encourage frank and open discussion. The Citizens Advice Bureaux were specially helpful in setting up group meetings with our prospective clients - low paid workers who would be affected by the NMW - many of whom were earning substantially below the chosen NMW. It was also useful to meet employers of low paid labour my own such visits included a chicken processing factory in Northern Ireland, care homes in Devon and a clothing manufacturer in Leicester - in their own workplaces. Such visits provided insights into how employers would react to different levels of NMW, including alterations to payment systems, work organisation and modifications to employment and hours. It has to be recognised, however, that there is a sample selection problem here: those employers least likely to comply with the NMW were also unlikely to volunteer to meet members of the LPC.

Debates within the LPC were frank but always with an underlying spirit of goodwill. Two main sub-groups met at certain times. The Economist Sub-Group grappled with employment, inflation and distribution issues; and the Youths and Training Group paid special attention to the concept and definition of bona fide training and the possible role of such training in justifying any lower youth rate. The LPC is tripartite, although the third party consists of independents, not representatives of the state. But it must not be concluded that initial disagreements on the adult or youth rates (see Sections 4 and 5) were along "them and us" lines with the independents in the middle. There was an array of views among both the union and employer representatives and on some matters one or more of the independents took a more robust line than either of the social partners.

At the outset George Bain stated that he wished for a unanimous report acceptable to the government. He achieved each goal save for minor alterations to the youth rate and age brackets. This partly reflects the spirit of social partnership among LPC members. Margaret Beckett, the then Secretary of State for Trade and Industry, stated (1998) of the LPC "your work [is] based on the partnership approach to which this government is committed". One member - Bill Callaghan, Chief Economist at the TUC - recently wrote (1998): "But it is in the LPC that the value of social partnership can most clearly be seen and few areas of my work at the TUC have been as satisfying as my membership of this body. Of course, the Commission's approach was not itself revolutionary: a balanced membership, recourse to evidence, and rational debate and consensus building have all been tried and tested before in Britain. In the light of recent history, however, the approach can be described as new". Another member, Stephanie Monk, Group HR 
Director at Granada, stated (see Overell, 1998): "The Commission is a powerful decision-making group. Every commissioner had a balance to strike between the constituency they were representing and the broader view. Some of the thought-provoking evidence we shared made it easier to put the interests in context. The principle is established, so it will never be so hard again". But George Bain's magisterial conciliation and mediation were also vital. In the final stages of discussions leading to our initial recommendations, he had to keep in mind the "ghosts at the bargaining table" - 10 and 11 Downing Street — without knowing their true position. Simultaneously he had to conciliate and mediate among coalitions (not formed on a "them and us" basis) with strong views on the adult rate and, in particular, any youth rate and its coverage.

It is worth dwelling on this notion of the LPC as an exemplar of social partnership as the LPC fits a little uneasily with earlier ideas of such a partnership and how it is viewed abroad. Social partnership implies that institutions and processes are in place such that differences between labour and capital can be settled by discussion, negotiation (and possibly conciliation and mediation). Thirty years ago — when some 9-in-10 employees had their pay determined collectively - collective bargaining was endorsed by the Donovan Commission (1968) as a vehicle for resolving such differences. Social partnership is a far more elusive and slippery concept than collective bargaining. Is it merely a statement of intent or does it represent a system of industrial relations?

At one level the notion of social partnership is just froth: a confection designed to minimise disagreements between workers and firms, a soothing phrase to massage dangerous historical differences. At another level it can be thought of as anti-state: regulation comes via employers and workers and their representatives, and in employee relations the state has only equivalent, or lower, status as these two parties. Alternatively social partnership can be viewed as a fully-fledged system of industrial relations. Until recently this was held to be the case in Germany. A recent book on the German system (Turner, 1997) states that Germany has a properly developed mechanism of social partnership: “...a framework for the regulation of a market economy... an approach to the negotiation of terms and conditions for the organisation of an advanced market economy - [consisting of]...negotiated agreements between strong and well organised employer associations and labour unions throughout the political economy, from wage bargaining, to vocational training to regularised input into economic policy making" (pp. 4, 255, 256).

Previous British attempts at social partnership were different from the German model (see Marginson, 1998, for fuller details). A largely adversarial system of industrial relations was supplemented with some partnership institutions, which were nearly always tripartite rather than consisting of just worker and employer representatives. Examples might include the Wages Councils, the Burnham Committee under which teachers' pay and conditions were settled for much of the post-war period and the Manpower Services Commission which was responsible for vocational training and the employment service in the 1970s. The experience of all these institutions suggests that when central decisions cannot be delivered at the workplace the partnership is liable to corrode.

Is the LPC an example of social partnership? Its members do not sit as representatives and have to have regard to the national interest as well as that of their own constituencies. To the extent that it was a three party partnership the independent members did not represent the state. Further, the coalitions within the LPC varied by issue (see Sections 3-5). Therefore the LPC was definitely not modelled along German lines with "negotiated agreements between strong and well organized employer associations and labour unions". Nevertheless, members of the LPC strove for and achieved consensus such that differences were settled by reasoned argument based on evidence. Stephen Dunn captures it nicely when he says "The LPC remind me of Laski's pluralism - committees consisting of various interest groups trying to make life more pluralistically reasonable". In this particular institution New Labour has rehabilitated unions and 
employers into a process which contrasts sharply with the "there is no such thing as society" confrontational Thatcher era.

But one swallow does not make a summer. Social partnership has little real substance if it only occurs in national institutions. Anyway, the counterpart national institutions to those which shape social partnership in other countries — the CBI, TUC and industry bargaining — are quite weak in the UK. A switch from adversarial relations to a so-called mutual gains system also requires partnership at workplace, firm and industry level as well as in national institutions. Recent evidence (eg Cully et al, 1998) suggests that the vacuum left by the decay of collective bargaining has not mainly been filled by works councils or fully-fledged human resource management systems embodying employee involvement and financial participation. Rather, authoritarian management is a more pervasive model - a far cry from social partnership.

\section{MAIN DEBATES AND RECOMMENDATIONS}

\section{Definition of the NMW}

There are three main issues surrounding the definition of the NMW (see LPC 1998 chapter 4). First, which components of the wage count towards the NMW? Second, which hours are to be paid at the NMW? Third, what is the pay reference period for the NMW calculation? The debates within the LPC on these thorny problems of definition were not really matters of principle. It was more a question of reaching a pragmatic, workable, easily understood definition which could deal with matters like home workers, payments by results, tips, sleepers in care homes and others who live in.

The LPC adopted a hybrid definition of pay, which includes certain components but not others. Essentially the definition includes all pay for standard working but excludes additional or premium payments. Thus the following components are included: bonuses, profit-related pay, merit pay and productivity payments; piece rates; sales commission; tips and gratuities paid to the worker via the employer; and free accommodation (only up to $£ 20$ a week). By contrast other components do not count towards the NMW: overtime or shift premia and call-out pay; special allowances for working in dangerous or unpleasant working conditions (eg working at heights or in water), standby and on-call allowances; London weighting and other location allowances; pension and life assurance contributions paid by employers; subsidised or free meals; staff discounts; and cash tips paid direct to a worker by a customer.

This hybrid definition seems fair to both employers and employees. If the NMW was limited to basic rates, it would have been unfair because it would undermine pay for performance practices. Equally, if the NMW were to include all earnings it would be unfair to workers because special allowances like overtime or shift premia are, by their nature, paid for non-standard working.

Hours which count towards the NMW are actual working time including overtime hours and any downtime when a worker is present at work but unable to work through no fault of their own. But other time for which the employee is paid (eg unauthorised absences, holidays etc) are not covered. This definition of working time is similar to that of the EU Working Time Directive - ie actual working time. The NMW is to be calculated over the worker's normal pay period up to a maximum of one month: the average hourly payment calculated over the pay reference period of one month was felt to be long enough to cover most fluctuations in earnings. 


\section{Choice of the NMW}

The main elements considered in coming to our decision on the NMW rate were quite straightforward but generated vigorous debate. Naturally the LPC took seriously the written and oral evidence and discussions with interested parties on site visits around the country. In addition, our "triangulation exercise" examined the previous Wage Council rates, international evidence and the coverage and cost of various potential NMWs. These will be considered in turn.

Wage Councils were axed in 1993 (see LPC 1998 Appendix 5). Their rates at the time of abolition provide an example of statutory minimum rates, which appear to have had no significant impact on employment (see Dickens et al (1997) and Fernie and Metcalf (1996) for a summary of the evidence). The employment-weighted Council rate at abolition was $£ 3.04$, equivalent to around $£ 3.90$ in April 1999 if uprated by the average earnings index (AEI). This rate was, for me at least, an upper bound for the initial NMW. There are a number of reasons for this. First, the NMW will apply to all industries, rather than just Wage Council trades, and average pay in some previously uncovered sectors such as business services and care homes was lower than Council rates at the time of their abolition in 1993 and remains so presently (see LPC (1998) Figure A2.1). Next, although $2.5 \mathrm{~m}$ people worked in Wage Council sectors, around $2 \mathrm{~m}$ were paid above the statutory minima; only some $0.3 \mathrm{~m}$ workers were paid at the council rates while the remaining $0.2 \mathrm{~m}$ were paid below, reflecting incomplete compliance with Council rates. Finally, the distribution of earnings has widened since 1993 partly, of course, as a consequence of abolition of the Councils. Hence a NMW set at the uprated Wage Council rate would have had a broader and deeper impact than the Council system at abolition.

It is tricky to compare minimum rates across countries. In the EU, for example, the minimum wage at purchasing power parity varied (April 1997) between $£ 1.65$ per hour in Portugal and $£ 4.56$ per hour in Belgium. But such figures are an unsatisfactory guide because average earnings vary so much across countries. Similarity, OECD and related evidence (Dolado et al, 1996) on the fraction of workers paid at the NMW in different countries needs to be used very cautiously because it refers to different time periods and uses different methods of estimation. In particular, the percentage at the spike of the distribution will decline between upratings. A somewhat more robust international comparator is minimum rates as a proportion of full-time median earnings. These ratios vary widely among OECD countries, between around $30 \%$ and just under $60 \%$ of full-time median pay (see Table 4, column 7), which in round terms equates to between $£ 2.40$ and $£ 4.80$ per hour in the UK in April 1998 (using New Earnings Survey (NES) data). But this too is an imperfect comparative measure as differences in earnings distributions imply that the same ratio may have a different effect on the labour market in different countries. The chosen NMW deflated to mid-1997 (£3.30) is equivalent to $44 \%$ of median full-time adult pay ( $43 \%$ of NES, $46 \%$ of Labour Force Survey (LFS)). Thus the UK is firmly in the middle of the international NMWs.

The coverage and cost of various potential NMWs were also central to our deliberations. This included both detailed analysis of the main sectors covered and possible knock-on effects on wage differentials and inflation. The NMW suggested by UNISON, TGWU and the Low Pay Unit was $£ 4.61$ ostensibly half male median earnings. This figure was calculated from NES data on full-time workers only, even though the majority of beneficiaries of the NMW are part-time. Further, the calculation takes the weekly earnings of full-timers, including overtime pay and divides it by weekly hours excluding overtime. Had the LPC plumped for this figure nearly 5 million employees ages $22+(1$ in 4$)$ would have been covered. On the other hand the figure of $£ 3.20$ suggested by some employers would only have covered around 1 million employees, or 5\% of these aged 22 and over. Some members of the LPC felt, partly on the basis of international evidence, that a reasonable upper limit on coverage was around $10 \%$ of all employees. As the 
number of youngsters covered was likely to be relatively high, this pointed to a coverage of some $8 \%$ for those aged $21+$.

The cost of the NMW mattered too. The Monetary Policy Committee of the Bank of England (1998a) and the Treasury were certainly concerned that the direct cost of the NMW should be well under $1 \%$ of the national wage bill. The LPC was also seized of potential knock-on effects. The low level of private sector unionisation, only around 1-employee-in-5 is a union member, coupled with decentralisation of collective bargaining suggests that any reasonable NMW would be unlikely to have serious consequences for pay differentials and so would probably not fuel wage inflation.

This oral and written evidence, site visits and analysis described in this section pointed, for me anyway, to a NMW of around $£ 3.60$ - the rate that was chosen. Details of the coverage and cost of the NMW are set out in Table 1 . Nearly 2 million workers will be affected by the NMW, half of whom are female part-time employees. The average pay rise for those affected will be around $30 \%$, but the introduction of the NMW will only add $0.6 \%$ to the national wage bill. Even allowing for any restoration of differentials the total cost is unlikely to be over $1 \%$ of the national wage bill. The rate of $£ 3.60$ puts the UK in the middle range of coverage by international standards - higher than the USA but below that in France - and it is comfortably within the uprated Wage Council rate.

\section{Youths}

The LPC terms of reference required us "to make recommendations on lower rates or exemptions for those aged 16-25". Leaving aside those aged 16 and 17, a cohort which virtually everyone who gave evidence, and all Commissioners, believed should be exempt from the NMW, the issues turned on the age at which the adult rate should start, the level of any youth rate and how a lower youth rate dovetailed with any training rate. Given that those aged 18-20 only represent $4 \%$ of employment, $6 \%$ of the working population and $16 \%$ of those in the lowest tenth by earnings the choice of the youth rate took up a disproportionate amount of time.

In their written and oral evidence most employers and unions leaned towards adult rates starting around the age 18/19 coupled with a lower "development" rate for those engaged in bona fide training. By contrast, academic evidence (eg Dickens et al, 1997) favoured lower youth rates up to around age 20-22. The government evidence (DTI, 1998a), strongly influenced by the Treasury, also argued for a lower rate for younger workers, hinting that 25 might be a suitable age for the full rate to start.

The youth rate recommended, and the suggested age brackets, reflected compromise within the LPC. The recommendation was for a rate of $£ 3.20$ (almost $90 \%$ of the adult rate) to apply to those aged 18-20, and those aged 21+ on a validated training course for up to 6 months. It is probably true that, among the members of the LPC, I took the strongest line in favour of a lower youth rate and extending that rate up to around age 22/23. My own arguments are set out in a companion paper (Metcalf, 1999) and summarised here in order to give the flavour of the debates within the Commission. I consider pay, jobs and unemployment and family incomes.

Average earnings rise with age and, correspondingly, the incidence of low pay declines dramatically with age up to around age 26. Younger workers have lower pay than prime age workers for a number of reasons. Youngsters are on average less productive because they lack labour market experience, and they also work disproportionately in sectors which, on average, pay lower wages. If 18-20 year olds were to be covered by the adult rate, half that age group would have their pay directly affected and the total wage bill for those aged 18-20 would rise by nearly a tenth. Evidence from OECD (1997) suggests that such a hike in labour costs would have put this vulnerable group at risk of job losses. 
Youths already have much higher unemployment rates than those aged 25+. Over the cycle the unemployment rate for those aged 18-19 is more than double the rate for those aged 25+. So, while it is true that the main cause of fluctuations in youth unemployment is movements in aggregate unemployment (with an elasticity of about 2), it is important not to set pay rates which might worsen the already high spot rate of youth unemployment. The need not to boost youth unemployment is compounded by the evidence that, ceteris paribus, a spell of unemployment when young worsens future labour market prospects (see eg LPC, 1998, para 5.25 and Nickell et al, 1985).

Any link between the NMW and family poverty is weaker for youths than for adults: the great majority of youngsters receiving the NMW live in families with two or more earners. Given that productivity and employment considerations pointed to a lower youth rate, if the adult rate had started at age 18 instead of age 22, it would, for me anyway, have had to be lower than $£ 3.60$ in order to accommodate youngsters. This, in turn, would have lessened the overall effect of the NMW on the household income distribution considered below.

In the event, the government did not fully accept the LPC's recommendations concerning youngsters. When introduced in April 1999 the rate will be $£ 3.00$ instead of the recommended $£ 3.20$ and the ages covered will be 18-21 inclusive instead of 18-20. Some in the government were concerned that the LPC recommendation was too high relative to corresponding median earnings. Its own proposals reduce the youth NMW from around three-quarters to around twothirds of the median and cut the increase in the wage bill from 3.9\% to 2.7\% (see Metcalf, 1999 Tables 4 and 5).

\section{Who Benefits from the NMW?}

Some workers are far more likely to be affected by the introduction of the NMW than others. Selected characteristics of those who will benefit are set out in Table 2. This shows, for example, that $11.3 \%$ (column 1) of females will have their pay directly raised by the NMW (compared with the authors' estimates of $7.6 \%$ for all workers). Females account for $69.8 \%$ (column 2) of workers affected (and therefore males the remaining 30.2\%) but only 46.9\% (column 3) of all workers. Therefore the odds (column 4) of females being affected are greater than unity, while they are correspondingly less than unity for men.

Workers disproportionately affected by the NMW include females, part-timers, youths, non-whites, those with short tenure, single parents and those with no other worker in the household. The table also sets out the attributes of the workplaces of such employees. They will be disproportionately in the private sector, in personal services like hairdressing or care homes or in hotels and restaurants. These workplaces are also unlikely to recognise a trade union and are more likely to be very small. Individuals who work from home, whose jobs are not permanent and who work at weekends, are all disproportionately likely to be affected by the NMW.

The 1998 Workplace Employment Relations Survey (see Cully et al, 1998) also contains interesting evidence on the incidence of low pay among workplaces, defined as having $25 \%$ or more employees earning under $£ 3.50$ an hour in mid-1998. The evidence (see Table 3 ) refers to a nationally representative sample of 1,890 workplaces with 25 or more employees. Low pay is overwhelmingly a private sector phenomenon: $93 \%$ of public sector workplaces had no workers earning below $£ 3.50$ and only $1 \%$ had a quarter or more of their workforce earning below it, compared with $13 \%$ of private sector workplaces. Within the private sector it is heavily clustered: in the WERS sample there were no workplaces in electricity, gas and water, transport and communications, and financial services where a quarter or more of the workforce are paid below $£ 3.50$ an hour. By the same measure, half of all workplaces in the hotel and restaurant industry had a quarter or more of the workforce earning below it at the time of the survey. Workplaces where unions were recognised were much less likely than their non-union counterparts to have a 
quarter of their workforce earning below $£ 3.50$ an hour. Further, the incidence of low pay declines monotonically with workplace size.

\section{INTERNATIONAL CONTEXT AND DISTRIBUTIONAL IMPACT}

Many countries have had a national minimum wage for decades so it is important to see how the UK fits into the wider international picture. This was touched on in Section 4 and fuller evidence from eight other major OECD countries is presented below dealing with the method by which the NMW is set, exclusions, the treatment of youths, the indexation or uprating method and the level and coverage of the respective minimum wages. The section concludes that cross-country comparative evidence suggests that the more workers are covered by a minimum wage, the lower is the associated wage dispersion. This, in turn, raises the question of the impact of the British NMW on pay and income inequality. The NMW is predicted to lower wage dispersion but its affect on the distribution of household income has, until recently, been rather uncertain and controversial. Completely new evidence is presented which suggests that the redistribution impact of the NMW will be rather greater than sometimes alleged.

\section{International Evidence on Minimum Wage Systems}

Nearly all OECD countries have some form of minimum wage setting arrangements. The Scandinavian countries set minimum wages via collective bargaining at sector level, but most other countries have a statutory or national minimum wage, which covers most sectors of the economy. An overview of the operation, exclusions, treatment of youths, uprating method and level of minimum wage in nine major OECD countries is set out in Table 4.

Most countries have a single national rate for adults, which can be monthly (eg Belgium), weekly (eg Australia) or hourly (eg Canada). Minimum wages are set at both national and regional levels in Canada and the US and at the regional level only in Japan. In the US only eight states set minimum wages above the federal level but in Canada each province sets its own hourly minimum. The United Kingdom has no regional variation - the LPC was specifically instructed to ignore such a possibility in its terms of reference. Exclusions vary from country to country. Many countries exclude apprentices and disabled workers. Some (eg Belgium and France) exclude many public sector employees, while others (eg Canada, USA) exclude groups of professional employees. In the UK the main exempt groups are those aged 16 and 17, the armed forces, some apprentices and share fishermen who are paid by a fixed share of their boat's catch.

The treatment of younger workers is a controversial issue internationally, not least because the OECD (1998) conclude, after exhaustive analysis, that "a rise in the minimum wage has a negative effect on teenage employment" (p.47). There is an array of approaches among the countries reported in Table 4. Canada, Spain and Japan do not set youth sub-minimum rates. France and the US have very limited lower rates. Australia, Belgium and the Netherlands have tapered rates from ages $22 / 20$ down to $16 / 15$. Thus the UK has a less sensitive age-wage progression for youths than these latter three countries but shows more flexibility than the other five countries.

Uprating methods also vary. In most countries minimum wages are set by the government unilaterally or following consultations with, or recommendations by, a tripartite body. But in Belgium the minimum is set via a national agreement between the social partners which is legally binding on all sectors. In Belgium the minimum wage is automatically linked to price inflation; in France, Japan and Spain both prices and wage movements are taken into account in annual reviews of the minimum rate. In the Netherlands the minimum is linked to movements in pay thereby ensuring that the low paid share in general prosperity - but this link can be suspended if unemployment rises above a specified level. In Austria and Spain the expected impact on 
inflation and employment is explicitly considered prior to any uprating. In the US and Canada there is no automatic uprating or indexation, which means movements in the minimum wage may be more susceptible to the composition of the government than otherwise. It is too early to determine the route the UK will follow. It seems probable that the LPC will be asked to make recommendations prior to any uprating. If and when there is agreement among the social partners and independent commentators that the NMW is about right, relative to other points on the pay distribution, then some form of automatic indexation might be considered. It is unlikely that such agreement will be forthcoming in the near future.

Finally, comparative evidence on the level of the NMW is presented. The dollar value (using purchasing power parities, PPPs) varies substantially among our nine countries, with the rate in Australia, Belgium and the Netherlands being more than double that in Spain. If the national currency is translated using official exchange rates rather than PPPs the dispersion in minimum rates is even larger. As discussed in Section 4 these absolute values of the minimum wage partly depend on how rich a country is so evidence is also presented on the minimum wage relative to the full-time median earnings. In France, Australia and Belgium the minimum is over a half of median earnings, while in Japan, Spain and the US the corresponding fraction is around one third. The British NMW - equivalent to $44 \%$ of median earnings - is in the middle of the nine country international league table on this indicator presented in Table 4.

OECD evidence shows (1998, Chart 2.3) that this latter minimum wage index (ie minimum wage as a percentage of median full-time earnings) is strongly negatively correlated across OECD countries with both earnings dispersion (measured by the ratio of median earnings to the upper limit of earnings received by the bottom $10 \%$ of full-time workers) and the incidence of low pay (measured by the percentage of full-time workers receiving less than two-thirds of median earnings). This implies that the NMW will be an important countervailing factor to the growth in wage inequality and incidence of low pay experienced by the UK economy in the last two decades. It may also influence the distribution of household income and it is to this that we now turn.

\section{The Impact of the NMW on the Distribution of Household Income}

The impact of the NMW on the distribution of pay, inflation, employment and exchequer finances has been set out in detail in a companion paper (Metcalf, 1999). The NMW will compress the earnings distribution with spikes appearing at $£ 3$ and $£ 3.60$ as those below these rates are brought up to them. It is likely that the NMW will have a once and for all effect on the price level of around $0.4 \%$ to $0.5 \%$ but no continuing effect on inflation. There is no strong evidence that, at the cautious initial rate, jobs will be lost. The trade associations in the affected sectors such as hospitality and security have mainly welcomed the NMW rate as "realistic"; and econometric analysis from the operation and axing of Wage Councils suggests that there would be no employment effects even if the rate had been set somewhat higher than $£ 3.60$. The impact of the NMW on exchequer finances is likely to be broadly neutral. On the spending side, any savings on means-tested benefits will probably be offset by a small rise in the public pay bill and extra procurement costs; on the revenue side, there will probably be only a minor change in taxation income flowing to the exchequer. Any rise in income tax, national insurance and VAT receipts will largely be offset by a fall in corporation tax. What is much less well established and somewhat controversial is the effect of the NMW on the distribution of income. The Institute for Fiscal Studies (IFS), which often focuses on all households, tends to suggest a minor redistributive role for the NMW (eg Gosling, 1996). By contrast Dickens and colleagues at the Centre of Economic Performance (eg Dickens and Machin, 1999) concentrate on samples of working families and demonstrate a much stronger impact of the NMW on income distribution. 
A full assessment of the impact of the NMW on the distribution of household income would need to take account of a number of factors other than pay changes by household. Prices of goods and services provided by the low paid may change relative to other product prices which could alter real purchasing power disproportionately by household decile income. Similarly, any extra public expenditure on goods and services produced by low wage workers is borne by society as a whole through the tax system and may therefore alter post-tax disposable incomes. Further, if firms bear the cost of the NMW then profits and stock market valuations will fall, so older people might bear more of the costs of the NMW as their imputed pension wealth decays. A NMW also directly affects the tax liability and benefit entitlement of the person whose pay has been raised. The competitive model predicts that the NMW might also reduce employment or boost unemployment, while the monopsonistic approach suggests that under some circumstances employment could be increased by the introduction of the NMW. Alternatively, work hours may be altered in response to the NMW. Any such changes in employment and hours will also influence the distribution of household income. Finally, the dynamic consequences of the NMW need to be assessed. How, for example, does it affect family income for people who go through the revolving door of low paid job-unemployment-low paid job?

No study has taken all such factors into account, it would be quite impossible to do so. But we are fortunate because Amanda Gosling of the Institute for Fiscal Studies and Richard Dickens of the Centre for Economic Performance have estimated the impact of the April 1999 NMW on household income incorporating some such effects.

Before turning to the evidence it is important to discuss two issues which have a major effect on any conclusions drawn from the impact of the NMW of distribution. First, should the unit of observation be households or benefit units? Gosling (1996) states: "Many households are made up of two or more benefit units living together - grown-up children living with their parents or couples looking after elderly relatives - and it may be the case that these sorts of households share their resources, so that a young person living at home is fully subsidised by his or her parents, for example. If this is the case it is wrong to consider single people with little independent income in rich households as poor" (p.43). Even though not all households will share income the use of households thus permits us to take account of any such income sharing among benefit units and in what follows we use households rather than benefit units as our observations.

Second, should the sample include all households, all households of working age or households with at least one adult worker? Many of the poorest households have no-one in work - pensioner or unemployed households for example. The NMW will surely have less impact on the distribution of income across households for a sample including such people than it will if the sample is limited to working households. We initially compare the distributional effects using all and working household, but subsequently focus on working households.

Evidence on households affected by the NMW, by decile income, is given in Table 5. This table takes account of direct changes in tax liability and benefit entitlement associated with the NMW. For the all household sample, the main beneficiaries of the NMW are in the middle of the income distribution. Fewer households towards the bottom are affected because so many of these are non-workers, including pensioners, the unemployed or the otherwise inactive. This evidence is sometimes used to dismiss any redistributional effects of the NMW. IFS (1998) recently concluded, for example, that: "the minimum wage will not redistribute income to poorer households". By contrast, if the sample is limited to working households an entirely different picture emerges. The table shows that over a quarter of households in the poorest decile gain and a fifth of those in the next poorest. The proportion of households affected declines monotonically by decile income. In what follows we confine our discussion to working households.

Richard Dickens has used the British Household Panel Survey consisting of some 4,500 working individuals per year with earnings information, to calculate the distribution of household income of those who gain and, just as important, how much they gain. These gains, unlike the IFS 
data above, are not adjusted for any modification in tax liability or benefit entitlement consequent on the introduction of the NMW. Rather the focus is on the direct impact of the NMW on pay, before any subsequent adjustments to benefits or taxes. The evidence in Table 6 is unambiguous. The NMW will alter the distribution of incomes in favour of those at the bottom of the distribution. First, individuals in households at the bottom of the income distribution are most likely to gain from the NMW. Over one fifth of households in the bottom quintile of the distribution gain whereas only $2.1 \%$ of those in the top half gain (column 1). Second, Dickens calculates that the NMW will raise the incomes of all working households, in aggregate, by $0.70 \%$. This is similar to the $0.6 \%$ hike in the aggregate wage bill estimated by the Office of National Statistics (see LPC, 1998). It is working households towards the bottom of the distribution who have their incomes raised by the biggest relative amounts (column 2). Those in the bottom quintile gain $2.83 \%$ (ie average of $4.18 \%$ plus $1.48 \%$ ) while those in the top half only gain $0.08 \%$. Third, the distribution of this $0.70 \%$ across households shows that the largest absolute gainers are the poorest households (column 3). Thus nearly two thirds of all gains go to the poorest fifth of households whereas the richest half of all households receive only $14 \%$ of the gains. Providing the analysis is limited to working households it is clear that the main gainers from the NMW are those towards the bottom of the distribution.

\section{AFTER THE REPORT}

The report of the LPC only signalled the beginning of the NMW story. The responses to the Report were generally favourable. During 1998/99 its recommendations have been translated into law via secondary legislation or Regulations. The state must enforce compliance with the NMW. Finally, the LPC has a continuing remit to monitor the implementation of the NMW and evaluate its impact, where liaison with academic colleagues as well as the social partners, is indispensable these issues are considered in turn.

\section{Responses}

Responses to the LPCs report were rather favourable. Both the Bank of England and Treasury were sanguine about the macroeconomic implications of the recommended NMW. The union movements were gracious about the work of the LPC but aspire, not surprisingly, to a higher rate. By contrast, the major pressure group for the low paid - the Low Pay Unit - was rather dismissive. The main business organisations were cautious but broadly welcomed the LPC's recommendations. In parliament, the Liberals supported the introduction of the NMW but the Conservatives opposed it, although they appeared unsure whether they would repeal the measure if returned to office.

Both the Bank of England (1998b) and the Treasury (1998) are relaxed about the level of the NMW. The Bank agreed with the LPC that the direct effect on the aggregate wage bill is to raise its level by $0.6 \%$. The Bank goes on the say that the overall impact on the aggregate wage bill and employment depends on a number of indirect factors. They include "the degree of differentials restoration higher up the wage distribution; the degree of market power that firms have over the labour market from which they recruit (the degree of monopsony); the degree of compliance with the law; the extent to which firms can offset the impact of the NMW on the total costs per hour by consolidating non-wage costs, for example cash tips; and the degree of substitutability between those covered by the NMW and other workers and capital". The Bank calculates that after allowing for these factors the aggregate wage bill will rise by $0.5 \%$. As some firms will have adjusted wages prior to April 1999 the Bank estimates that half of the full effect will come through before then. The Bank does not anticipate that the NMW will result in a wage- 
price spiral, it estimates simply "a small positive effect of about $0.4 \%$ on the price level". Essentially the Bank sees the introduction of the NMW as a modest once and for all shock which will raise the price level but have no effect on the inflation rate after one year.

The Treasury (1998) paid considerable attention to the employment effects of the NMW. After studying the impact of the Wage Councils on employment, international evidence and undertaking simulations using their own macroeconomic models, the Treasury concluded that a NMW in the range of $£ 3.50$ to $£ 3.80$ "will probably only have a small adverse effect on employment. The effect could well be close to zero and is unlikely to exceed 100,000 jobs".

The union movement responded very kindly to the NMW even though the figure of $£ 3.60$ is $£ 1$ below the $£ 4.61$ target figure adopted unanimously by the TUC in September 1998. Thus Rodney Bickerstaffe of UNISON - the midwife of the NMW - writes (1998) of being "cock-ahoop, proud that we now have, for the first time in our time, a minimum wage law in this country below which no one will be exploited". The LPC Report "will rank with the great social reports of the post and pre-war years". Similarly John Monks, General Secretary of the TUC, described the Report as "a milestone in twentieth century industrial relations" and pointed out that without the unanimous report from the LPC the rate would have been less than $£ 3.60$ an hour and the challenge facing the unions was to recruit the $83 \%$ of workers earning less than that figure who were not unionised (reported in Financial Times, 16 September 1998).

Nevertheless, the union movement clearly believes that the rate has been set too low. At the 1998 TUC Bill Morris, General Secretary of the TGWU, said "Thank you for the principle, shame about the rate" and together with other general secretaries called for a £4.61 NMW (ostensibly half the male median) and a minimum wage for unions who bargain collectively of $£ 5$ an hour. It is legitimate for unions to choose any figure they want but what is sacrosanct about half the male median? Why half, why male, why median? The recommendation for the initial NMW by the LPC was deliberately prudent. There may well be a good case for a somewhat higher rate, but it needs to be argued out, not asserted as a self-evident truth.

In parliament the Conservative spokesman in the Commons, John Redwood, stated (Hansard, 28 July 1998, column 217) that the DTI has brought forward "a large number of bad proposals... including the national minimum wage". Although his spokeswoman in the Lords, Baroness Miller of Hendon, said (Hansard, 27 July 1998, column 1201) that "we are totally opposed to the national minimum wage... yes, indeed, we are", Mr Redwood was not prepared to go so far: "I have never said that we shall abolish the minimum wage" (Hansard, 28 July 1998, column 217). Rather he promised a review which, if it did not plump for abolition would focus on exemptions, as set out by Baroness Miller: "discretionary power to make exemptions to the national minimum wage in cases of different areas, sectors of employment, undertakings of different sizes, persons of different ages and persons of different occupations" (Hansard, 20 July 1998, column 584).

Organisations representing small firms in general and those firms in hospitality and security - two large sectors where the NMW will affect labour costs - have supported the LPC's recommendations. The British Chamber of Commerce (1998) stated that "£3.60 strikes a reasonable balance for the economy as a whole" and was also "pleased" about the exemptions of those aged 16-17 and the lower youth rates for those aged 18-21. The President of the British Hospitality Association (1998) welcomed the "very positive and realistic way" in which the LPC has approached the setting of the NMW... "If a decent floor can be put under wages, without damaging jobs we can live with it and, indeed, the association is committed to making the minimum wage work in practice". The CEO of Pinkerton, a major security company stated (Personnel Today, 24 September 1998) that almost all of his clients where guards were presently paid below $£ 3.60$ would be content to pay the extra costs of the NMW. Indeed "anyone who is not prepared to pay those levels is not the type of client we want to be dealing with". The major discordant note within the business community came from Sir Clive Thompson, the President of 
the CBI and CEO of Rentokil Initial, who warned that thousands of his poorly paid workers could lose their jobs because of the NMW. His claim was not greeted sympathetically. For example the normally pro-business Express on Sunday commented (23 August 1998) that "if there was a charge of bringing British business into disrepute then Thompson should be in the dock".

The main pressure group for the low paid - the Low Pay Unit — when under the then direction of Chris Pond, played a pivotal role in getting the concept of a National Minimum Wage accepted by both the Labour Party and TUC. But a NMW of $£ 3.60$ an hour, boosting the pay of nearly 2 million employees by nearly a third on average, clearly falls well short of the Unit's aspirations. The LPC's approach is described (Low Pay Unit 1998) as "overcautious and business-orientated, leaning towards existing discriminatory payment systems, [which] has created a system which is in danger of institutionalising low pay". There is no analysis backing up such criticism. Instead the LPU simply state that they use something called "the Council of Europe's decency threshold (68\% of national average earnings)" as their target. This would produce a figure of around $£ 7$ an hour covering "more than 10 million employees". The LPU article does not discuss the inflation or employment consequences of such a figure.

Perhaps more surprising is the associated LPU analysis of Sachdev and Wilkinson (1998). First, they compare the absolute levels of the minimum wage in the UK and US and state dismissively that the NMW "is worth less than the notoriously low US minimum wage". This is not so (see Table 4). The British NMW is worth more than the US minimum wage, it is a higher fraction of median earnings and it covers a higher proportion of workers than the US minimum wage. Second, they compare the coverage of the NMW (approx 1.9m employees) with the number of workers employed in the ex-Wage Council sectors (approx 2.5m) and assert "the minimum wage covers 600,000 fewer employees than the Wage Councils did prior to their abolition". They are either unaware, or choose to ignore, that 4-in-5 employees in Wage Council industries earned above the council minima in 1993 at the time of their abolition. In fact the NMW will cover some four times the number paid at or below the minimum in the ex-council sectors. It is vital that the LPC's Report is critically scrutinised, but it is to be hoped that the low paid achieve a more thorough evaluation than that thus far provided by the pressure group who campaigns on their behalf.

\section{Regulations}

The National Minimum Wage Bill was introduced into the House of Commons on 26 November 1997 and received Royal Assent on 31 July 1998. The Act establishes the legislative framework for the NMW. It provides a number of powers ("delegated powers") to make secondary legislation to determine key issues such as the NMW rate, exemptions and modified rates, the pay reference period which will be applied, what payments will count in deciding whether the NMW has been paid, record keeping requirements and a written NMW statement. Thus the recommendations of the LPC are translated into law via secondary legislation or regulations. It is no mean feat to draft these regulations - the relevant document (DTI, 1998b) runs to 125 pages. Consider some examples.

Regulation 3(3) provides that periods when the worker is absent from work (eg absence for sickness, holidays) do not count as time when the NMW is payable. The principle of the NMW is to provide that workers must be paid a minimum for the work they do, not to provide rights for pay periods of absence. A worker may, of course, be entitled to payments for certain absences under other legislation (eg statutory sick pay, statutory maternity pay, guaranteed payments for lay-offs and holiday pay under the Working Time Regulations) but it is not the purpose of the NMW to give any additional right to payments for these periods.

The definition of a "worker" who qualifies for the NMW is contained in Section 54 of the NMW Act. It is based on the wide definition in Section 230(3) of the Employment Rights Act 
1996 which covers not only those who have contracts of employment ("employees"), but also individuals who "do not perform personally any work or services for another party to the contract whose status is not that of a client or customer of the worker" (DTI, 1998b p.93). Such a definition is intended to exclude only those who are genuinely in business on their own account. It includes, for example, agency workers and most homeworkers. The only groups who are excluded from the NMW are: the genuinely self-employed; children under minimum school leaving age (this age-based exemption is extended in the Regulations to those aged under 18); serving members of the Armed Forces; share fishermen and directors of companies.

Deductions by the employer from the NMW in respect of living accommodation is set out in regulation 25. Where the individual is paid hourly the calculation is as follows: multiply hours by 50p and reduce the total proportionately for days in the pay reference period when accommodation was not provided. For example, for a worker who works 28 hours a week but for whom accommodation was not provided on one day that week, the amount that counts towards the NMW will be: $28 \times 50 p=£ 14$ minus one-seventh of $£ 14=£ 12$.

Similar regulations are required for definitions of working time, accredited training, allowances, exemptions of apprenticeships, the pay reference period, hours for "timed work", the calculation of the hourly rate for piece rates, what money counts toward the NMW, the right to a written pay statement and records to be kept by an employer. Thus DTI officials still had much work to do even after the LPC had reported.

\section{Enforcement}

Enforcement of the NMW was outside the Terms of Reference of the LPC, but the Commission did make recommendations (LPC, 1998, chapter 8) concerning the importance of publicising the NMW by stating the rate on pay statements and on posters in the workplace as well as the possibility for an employee to report her employer anonymously to that agency. It also suggested that the Government should consider carefully the Contributions Agency as the enforcement agency.

The Government accepted these recommendations: employers are required to keep records of pay and hours and provide a worker with right of access to such records. Enforcement action can be initiated both by individuals and by officers of the Enforcement Agency. The Government has announced that inspection and enforcement is to be via the merged Inland Revenue and Contributions Agency. If a worker believes that she is not being paid the National Minimum Wage she can, having given notice to the employer, inspect the employer's records and can be accompanied by another person - for example a trade union official. Refusal to allow access to the records is grounds for complaint to an industrial tribunal, which may require the employer to pay the worker 80 times the hourly amount of the NMW if the complaint is upheld. If the worker believes she is, or has been, underpaid she has three options. She can take her case to an employment tribunal, where there is a reverse of the burden of proof: the employer has to prove that s/he did pay the National Minimum Wage. Alternatively, she can go to a civil court to enforce her contractual entitlement to recover the difference between what she has been paid and the NMW. Again the onus is on the employer to demonstrate compliance. The third option is to draw the problem to the attention of the Enforcement Agency, for them to take up the case.

Enforcement officers have the power to issue an enforcement notice to require an employer to pay the NMW, including making good any underpayment. If such a notice is ignored, the officer has the capacity to bring the case to an employment tribunal on behalf of the individual worker and/or to impose a financial penalty of twice the hourly NMW per worker per day of continuing non-payment. Thus a firm which continued to underpay 7 workers would be required to pay a penalty of $£ 50.40$ per day at the introductory NMW. An employee must not be dismissed, or suffer any other detrimental action, for complaining she is paid below the NMW or 
for informing the enforcement officer or because the employer is prosecuted. Any such dismissal or action can be declared unfair by an employment tribunal and the employee eligible for compensation.

Enforcement officers also have the power to prosecute six criminal offences: refusal or wilful neglect to pay the NMW; failing to keep NMW records; keeping false records; producing false records; intentionally obstructing an enforcement officer; and refusing to give information to an enforcement officer. Equally, a third party who commissions any refusal to pay the NMW or a failure to keep records is guilty of an offence. The maximum fine for each offence is $£ 5,000$.

The level of the NMW is likely to be well known. Full compliance with it requires two elements: a good chance that underpaying firms will be caught, and a suitable punishment when they are caught. The inspection apparatus to detect underpayment seems suitably wide-ranging. The level of punishments will, however, need to be kept under review. The fines do not seem excessive when compared, for example, with penalties imposed on those defrauding social security.

\section{Monitoring and Evaluation}

The LPC has been asked to monitor and evaluate the first phase of implementation of the NMW and to report on this by the end of 1999. This will involve in-house research, commissioning external research and sustaining its strong links with the academic community. It is not a straightforward matter to identify the effects of the NMW, not least because so many other changes are taking place, including the economic cycle, the Working Time Directive, the New Deal and tax and benefit reform. The evaluation exercise will be comprehensive but there are some sectors - eg retail, hospitality, business services, care homes - and some groups - eg youths, homeworkers - where the effects are likely to be greater.

Research on evaluation will cover three phases associated with the initial and longer term aspects of the LPC's work. First, pre-implementation: a baseline will be established from which we can detect changes once the NMW is introduced. It is also necessary to assess adjustments as firms prepare for the introduction of the NMW in April 1999; for example there is evidence (IDS, 1997) that many firms were altering their pay structures in 1997 and 1998 so the NMW itself could be smoothly phased-in a year later. Second, early post-implementation: this will enable the LPC to advise by end-1999 on any changes to be introduced for June 2000, including the effect on 21 year olds and the New Deal. Third, longer term effects: these may take several years to appear and will be central to any recommendation on resetting the rate.

Economy-wide factors which will be considered include: the number and type of people affected, including the distribution of pay increases; business costs, particularly among small firms, including any impact on pay differentials; prices and productivity movements in the aggregate economy and by sector; training, including the take-up of modern apprenticeships and accreditation; impact on the public sector borrowing requirement (PSBR) and public sector pay. Much of the requisite information is routinely available through surveys like LFS or NES - there is plenty of information, the intellectual challenge turns on its interpretation.

The process by which employers and employees react to the NMW is important and detailed surveys and case studies will be required to shed light on such behavioural effects. The sorts of issues to be investigated include: restoration of pay differentials; substitution of younger for older workers; the way firms adjust to increased business costs; avoidance and evasion mechanisms such as a shift to self-employment; impact of higher pay on work incentives; changes in composition of earnings and in the provision of non-wage benefits. Some before and after studies are already underway at, for example, LSE (care homes), Warwick (clothing, printing) and Manchester (hotels and restaurants) and these academic studies will provide key evidence for the LPC on the behavioural responses of organisations to the introduction of the NMW. 
The LPC secretariat has summarised the research agenda on a number of issues including business costs, productivity, employment, training and development, inflation, public sector finances, pay structures and working time charges and enforcement. By way of example the ambitious nature of the research programme envisaged on pay structures and working time changes is set out in Table 7. It will be seen that it includes both economy-wide and firm-specific issues like changes in the composition of pay and associated benefits. Correspondingly detailed agendas exist for the other items. It is unlikely that the entire programme will be completed by end-1999, but the LPC has thought through its monitoring and evaluation remit quite carefully. It is here that the contribution of the research community is of paramount importance and the LPC members and secretariat look forward to working with such scholars to further improve our understanding of the national minimum wage. 
Table 1

Coverage and Cost of The National Minimum Wage

\begin{tabular}{|c|c|c|c|c|}
\hline group & $\begin{array}{c}\text { numbers affected } \\
(000 s)\end{array}$ & $\%$ of group affected & $\begin{array}{c}\text { increase in wage } \\
\text { bill }(\%)\end{array}$ & $\begin{array}{c}\text { average increase for } \\
\text { those affected }(\%)\end{array}$ \\
\hline all $18+$ & 1,903 & 8.3 & 0.6 & 30 \\
\hline $18-21$ & 221 & 14.0 & 2.7 & 30 \\
\hline $22+$ & 1,683 & 7.8 & 0.6 & 30 \\
\hline male full-time & 357 & 3.2 & 0.3 & - \\
\hline male part-time & 211 & 20.5 & 3.5 & - \\
\hline female full-time & 335 & 5.6 & 0.6 & - \\
\hline female part-time & 1,001 & 19.7 & 2.7 & - \\
\hline
\end{tabular}

Source: LPC (1998) Table 7.1, updated using information from April 1998 NES and Spring 1998 LFS.

Notes:

1. Estimates are based on ONS central method combining information from the NES and LFS see Wilkinson (1998) for full details of the method.

2. Rates for April 1999 have been deflated back to Spring 1998 by the forecast change in the RPI to yield benchmarks of $£ 2.90$ for those aged $18-21$ and $£ 3.50$ for those aged $22+$. Alternatively 10p can be added to the initial 1999 rates so that the NMW figure of $£ 3.60$ is equivalent to an average earnings figure of $£ 3.70$ reflecting eg overtime and shift premia and the London allowance. The $£ 3.70$ can then be deflated by the AEI, which again translates into an earnings figure of $£ 3.50$ in Spring 1998. 
Table 2

Characteristics of Workers Affected by The National Minimum Wage

\begin{tabular}{|c|c|c|c|c|}
\hline \multirow{2}{*}{ characteristics } & $\begin{array}{c}\text { \% of group } \\
\text { affected }\end{array}$ & $\begin{array}{l}\% \text { of minimum } \\
\text { wage workers } \\
\text { in the group }\end{array}$ & $\begin{array}{c}\% \text { of all } \\
\text { workers in the } \\
\text { group }\end{array}$ & \multirow{2}{*}{$\begin{array}{c}\text { odds of being a } \\
\text { minimum wage } \\
\text { worker col.2) col.3 } \\
4 \\
\end{array}$} \\
\hline & 1 & 2 & $\mathbf{3}$ & \\
\hline \multicolumn{5}{|l|}{ individual } \\
\hline female & 11.3 & 69.8 & 46.9 & 1.5 \\
\hline part-time & 18.5 & 57.3 & 23.5 & 2.4 \\
\hline age $18-21$ & 12.0 & 11.5 & 6.0 & 1.9 \\
\hline non-white & 10.0 & 5.9 & 4.5 & 1.3 \\
\hline in job for under 6 months & 14.2 & 20.4 & 10.9 & 1.9 \\
\hline single parent & 17.4 & 6.5 & 2.8 & 2.3 \\
\hline no other workers in household & 8.5 & 30.8 & 27.4 & 1.1 \\
\hline \multicolumn{5}{|l|}{ workplace } \\
\hline private sector & 9.0 & 87.2 & 68.2 & 1.3 \\
\hline personal service worker & 22.7 & 17.8 & 6.0 & 3.0 \\
\hline hotels \& restaurants & 27.9 & 14.9 & 4.0 & 3.7 \\
\hline no union recognition & 11.2 & 82.8 & 55.7 & 1.5 \\
\hline in firm with under 10 employees & 16.9 & 40.0 & 17.9 & 2.2 \\
\hline no permanent job & 11.1 & 9.9 & 6.7 & 1.5 \\
\hline home worker & 21.9 & 4.5 & 1.6 & 2.8 \\
\hline works Saturdays & 11.2 & 33.0 & 22.3 & 1.5 \\
\hline works Sundays & 12.0 & 18.7 & 11.9 & 1.6 \\
\hline all workers & 7.6 & 100 & 100 & 1.0 \\
\hline
\end{tabular}

Source: Dickens and Machin (1998).

Notes:

1. Figures calculated from quarterly LFS.

2. The per cent of all workers affected $(7.6 \%)$ is slightly below the most recent corresponding LPC estimate (8.3\%). This is because the LPC allow for the fact that the NMW of $£ 3.60$ is equivalent to an earnings figure of around $£ 3.70$ once any overtime premia have been incorporated (see Table 3). 
Table 3

Low Pay by Workplace Characteristics

\begin{tabular}{|c|c|}
\hline characteristics & $\begin{array}{c}\% \text { of workplaces with } 25 \% \text { or more employees } \\
\text { earning less than } £ 3.50 \text { per hour }\end{array}$ \\
\hline \multicolumn{2}{|l|}{ workplace size (employees) } \\
\hline $25-44$ & 12 \\
\hline $50-99$ & 8 \\
\hline $100-199$ & 6 \\
\hline $200-499$ & 4 \\
\hline $500+$ & 2 \\
\hline \multicolumn{2}{|l|}{ industry } \\
\hline manufacturing & 5 \\
\hline electricity, gas, water & 0 \\
\hline construction & 1 \\
\hline retail and wholesale & 8 \\
\hline hotels and restaurants & 48 \\
\hline transport and communications & 0 \\
\hline financial services & 0 \\
\hline other business services & 10 \\
\hline public administration & 0 \\
\hline education & 2 \\
\hline health & 17 \\
\hline other community services & 19 \\
\hline \multicolumn{2}{|l|}{ type of union presence } \\
\hline no union presence & 16 \\
\hline unions present, no recognition & 9 \\
\hline unions recognised & 2 \\
\hline all workplaces & 9 \\
\hline
\end{tabular}

Source: Cully et al (1998) Table 10.

Note: Base is all workplaces with 25 or more employees; figures are weighted and based on responses from 1,890 managers. 
Table 4:

Summary of Minimum Wage Systems in Selected OECD Countries with a National Minimum

\begin{tabular}{|c|c|c|c|c|c|c|}
\hline $\begin{array}{c}\begin{array}{c}\text { country } \\
\text { (year of } \\
\text { introduction) }\end{array} \\
\text { (1) }\end{array}$ & $\begin{array}{c}\text { type of } \\
\text { determination } \\
\text { (2) }\end{array}$ & (3) & $\begin{array}{c}\begin{array}{c}\text { youth rates } \\
\text { \% of adult }\end{array} \\
\text { (4) }\end{array}$ & $\begin{array}{c}\text { indexation or } \\
\text { uprating } \\
\text { procedures }\end{array}$ & $\begin{array}{l}\text { end } 1997 \\
\text { NMW in } \\
\text { \$US using } \\
\text { PPPs } \\
\text { (6) }\end{array}$ & $\begin{array}{c}\text { mid-1997 } \\
\text { NMW as \% } \\
\text { of full-time } \\
\text { median } \\
\text { earnings } \\
\text { (7) }\end{array}$ \\
\hline $\begin{array}{l}\text { Australia } \\
\text { (1996, some } \\
\text { form since } \\
1907)\end{array}$ & $\begin{array}{l}\text { statute, } \\
\text { underpins } \\
\text { sectoral minima, } \\
\text { weekly }\end{array}$ & $\begin{array}{l}\text { some well } \\
\text { paid } \\
\text { professional } \\
\text { sectors }\end{array}$ & $\begin{array}{l}\text { tapered: } \\
\text { age: } 16 \ldots 20 \\
\%: 40 \ldots 85\end{array}$ & $\begin{array}{l}\text { independent body } \\
\text { considers } \\
\text { economic factors } \\
\& \text { needs of low } \\
\text { paid }\end{array}$ & 6.65 & 54 \\
\hline $\begin{array}{l}\text { Belgium } \\
(1975)\end{array}$ & $\begin{array}{l}\text { National } \\
\text { collective } \\
\text { agreements, } \\
\text { monthly }\end{array}$ & $\begin{array}{l}\text { public sector, } \\
\text { apprentices, } \\
\text { some disabled }\end{array}$ & $\begin{array}{l}\text { tapered: } \\
\text { age: } 20 \ldots 16 \\
\%: 94 \ldots 70\end{array}$ & $\begin{array}{l}\text { central agreement } \\
\text { renegotiated every } \\
2 \text { years. Indexed } \\
\text { to CPI in between }\end{array}$ & 6.40 & 50 \\
\hline $\begin{array}{l}\text { Canada } \\
\text { (Women } \\
1918-30) \\
\text { Men }(1930- \\
59)\end{array}$ & $\begin{array}{l}\text { Statute, Federal } \\
\text { and Provincial, } \\
\text { hourly }\end{array}$ & $\begin{array}{l}\text { some } \\
\text { apprentices, } \\
\text { farm workers, } \\
\text { managerial } \\
\text { workers }\end{array}$ & no & $\begin{array}{l}\text { no automatic } \\
\text { indexation }\end{array}$ & 5.33 & 40 \\
\hline $\begin{array}{l}\text { France } \\
(1950,1970 \\
\text { in current } \\
\text { form })\end{array}$ & $\begin{array}{l}\text { statute, national, } \\
\text { hourly }\end{array}$ & $\begin{array}{l}\text { general govt, } \\
\text { some disabled }\end{array}$ & $\begin{array}{l}\text { for under } 6 \\
\text { months tenure } \\
1790 \% \\
1680 \% \\
\end{array}$ & $\begin{array}{l}\text { indexed to CPI } \\
\text { must rise by at } \\
\text { least half the rise } \\
\text { in AEI }\end{array}$ & 5.56 & 57 \\
\hline $\begin{array}{l}\text { Japan } \\
(1959,1968 \\
\text { in current } \\
\text { form) }\end{array}$ & $\begin{array}{l}\text { statute, for each } \\
\text { of the } 47 \\
\text { prefectures, } \\
\text { hourly and daily }\end{array}$ & $\begin{array}{l}\text { apprentices, } \\
\text { disabled, } \\
\text { new hires on } \\
\text { probation } \\
\text { some civil } \\
\text { servants } \\
\end{array}$ & no & $\begin{array}{l}\text { tripartite, local } \\
\text { revised a every } \\
\text { year on basis of } \\
\text { changes in CPI, } \\
\text { AEI }\end{array}$ & 3.38 & 31 \\
\hline $\begin{array}{l}\text { Netherlands } \\
\text { (1968) }\end{array}$ & $\begin{array}{l}\text { statute, national, } \\
\text { daily, weekly, } \\
\text { monthly }\end{array}$ & $\begin{array}{l}\text { covers all } \\
\text { employees } \\
\text { with a labour } \\
\text { contract } \\
\end{array}$ & $\begin{array}{l}\text { tapered } \\
\text { age: } 22 \ldots 15 \\
\%: \quad 85 \ldots 30\end{array}$ & $\begin{array}{l}\text { linked to change } \\
\text { in AEI but } \\
\text { indexation can be } \\
\text { suspended }\end{array}$ & 6.00 & 49 \\
\hline $\begin{array}{l}\text { Spain } \\
\text { (1963, } 1976 \\
\text { in current } \\
\text { form) }\end{array}$ & $\begin{array}{l}\text { statute, national, } \\
\text { monthly }\end{array}$ & no exemptions & no & $\begin{array}{l}\text { uprated annually } \\
\text { after tripartite } \\
\text { consultation } \\
\text { including } \\
\text { consideration of } \\
\text { inflation and } \\
\text { economic } \\
\text { performance }\end{array}$ & 2.94 & 32 \\
\hline $\begin{array}{l}\text { United States } \\
(1938)\end{array}$ & $\begin{array}{l}\text { statute, Federal } \\
\text { and State, } \\
\text { hourly }\end{array}$ & $\begin{array}{l}\text { Executive } \\
\text { administration } \\
\& \text { other } \\
\text { specific, small } \\
\text { groups }\end{array}$ & $\begin{array}{l}\text { under } 20 \\
\text { first } 90 \text { days } \\
83 \%\end{array}$ & $\begin{array}{l}\text { no automatic } \\
\text { indexation }\end{array}$ & 5.15 & 38 \\
\hline $\begin{array}{l}\text { United } \\
\text { Kingdom } \\
(1999)\end{array}$ & $\begin{array}{l}\text { statute, national, } \\
\text { hourly }\end{array}$ & $\begin{array}{l}\text { some } \\
\text { apprentices, } \\
\text { armed forces, } \\
\text { share } \\
\text { fishermen, } \\
16-17 \text { y.o. }\end{array}$ & $\begin{array}{l}\text { 16-17 exempt } \\
18-2183 \%\end{array}$ & $\begin{array}{l}\text { no automatic } \\
\text { indexation }\end{array}$ & 5.44 & 44 \\
\hline
\end{tabular}




\section{Table 4 continued}

Sources: OECD (1998, chapter 2), LPC (1998, Appendix 6).

\section{Notes:}

1. Purchasing power parity (PPP, column 6) is the hypothetical rate of currency conversion that eliminates the differences in price levels between countries.

2. The median earnings figure (column 7) of full-time workers includes overtime and bonus components.

3. For countries where the minimum wage is not usually expressed as an hourly rate, the actual rate in column 2 and 3 has been converted to an hourly basis assuming a working time of 8 hours a day, 40 hours a week and 173.3 hours per month.

4. $\mathrm{CPI}$ is consumer price index, $\mathrm{AEI}$ is average earnings index.

5. The UK minimum wage of $£ 3.60$ per hour in April 1999 is deflated back by the AEI to end/mid-1997 and the corresponding figure of $£ 3.40$ used in the calculations for columns (6) and (7). 
Table 5

Households Affected by April 1999 NMW

\begin{tabular}{ccc}
\hline income decile & $\begin{array}{c}\text { all households } \\
\text { \% }\end{array}$ & $\begin{array}{c}\text { working households } \\
\text { \% }\end{array}$ \\
\hline & & \\
bottom & 3.7 & 29.4 \\
2 & 6.2 & 20.4 \\
3 & 7.3 & 15.0 \\
4 & 8.4 & 13.5 \\
5 & 8.8 & 1.2 \\
6 & 9.5 & 8.3 \\
7 & 8.0 & 6.2 \\
8 & 6.1 & 3.6 \\
9 & 2.6 & 2.5 \\
top & 2.0 & 2.1 \\
\hline
\end{tabular}

Source: Supplied by Amanda Gosling, Institute for Fiscal Studies. Calculated from 1995/96 Family Resources Notes: Survey, updated to 1999. Tax and benefit regime as at April 1998.

1. Method of calculation is as follows: the individual is assigned the net income per adult equivalent of the household of which he or she is a member. So the construction of the income measure takes place at the household level. Thus only $3.7 \%$ of all households in the bottom $10 \%$ of the income distribution are affected by the NMW but $29.4 \%$ of working households in the bottom $10 \%$ of the income distribution are affected.

2. Coverage as for NMW, viz workers under 18 excluded, 18-21 receive $£ 3.00,22+$ receive $£ 3.60$

3. Working sample refers to households with at least one adult (aged 18+) worker.

4. Equivalence scales are used to correct income for differential household size, see McClements (1997) for full details. 
Table 6

Distribution of Gains from April 1999 NMW among Working Households

\begin{tabular}{lccc}
\hline household income decile & $\%$ affected by NMW & $\begin{array}{c}\text { wage gap as \% of total } \\
\text { household income }\end{array}$ & $\begin{array}{c}\text { \% distribution of } \\
\text { aggregate gains }\end{array}$
\end{tabular}

(1)

(2)

(3)

\begin{tabular}{lccc}
\hline & 29.9 & 4.18 & 39.8 \\
bottom & 12.9 & 1.48 & 24.0 \\
2 & 9.9 & 0.49 & 9.7 \\
3 & 6.9 & 0.33 & 7.9 \\
4 & 4.0 & 0.17 & 4.6 \\
5 & 3.1 & 0.19 & 5.5 \\
6 & 2.6 & 0.08 & 2.8 \\
7 & 2.4 & 0.08 & 3.0 \\
8 & 1.4 & 0.01 & 0.1 \\
9 & 1.1 & 0.04 & 2.5 \\
top & & & $\mathbf{1 0 0}$ \\
All deciles & $\mathbf{7 . 4}$ & $\mathbf{0 . 7 0}$ & \\
\hline
\end{tabular}

Source: Supplied by Richard Dickens, Centre for Economic Performance, LSE. Calculated from British Household

Notes:

Panel Survey 1996/7. April NMW reflated forwards to 1999 by AEI.

1. The evidence is calculated as follows. Each working individual is assigned his/her household income. The deciles are then imputed for individuals according to their equivalent household income. Thus for working individuals whose household income is in the bottom decile, $29.9 \%$ are affected by the NMW, their household income will rise by $4.18 \%$ consequent on the introduction of the NMW and their households receive $39.8 \%$ of the total household gains from the NMW.

2. Working household defined as having at least one individual in employment.

3. Equivalence scales are used to correct income for differential household size, see McClements (1997) for full details. 
Table 7

Pay Structures and Working Time Changes

\begin{tabular}{|c|c|}
\hline issues & methodology/comments \\
\hline Changes in the overall composition of pay. & $\begin{array}{l}\text { NES will provide data on any changes in the proportions of PBR, } \\
\text { overtime and shift pay for low paid employees, although will } \\
\text { need to allow for effect of other economic factors (eg level of } \\
\text { overtime working in the economy as a whole). By industry and } \\
\text { occupation. }\end{array}$ \\
\hline $\begin{array}{l}\text { Changes in overtime and shift premia. Will } \\
\text { employers seek to consolidate overtime and shift } \\
\text { premia into basic pay? }\end{array}$ & $\begin{array}{l}\text { Sectoral studies should provide some evidence. Could also ask } \\
\text { IDS/IRS to include questions in their periodic studies of overtime } \\
\text { and shift working. }\end{array}$ \\
\hline $\begin{array}{l}\text { Changes in incentive pay practices (eg bonuses, } \\
\text { piecework \& commission). How employers treat } \\
\text { bonuses outside the pay ref period (eg whether } \\
\text { paid monthly)? }\end{array}$ & $\begin{array}{l}\text { Sectoral studies of key areas (eg textiles and clothing, retail, } \\
\text { agriculture). Could be picked up as part of wider sectoral impact } \\
\text { studies. Or commission research from IDS/IRS? Union } \\
\text { intelligence - GMB, NUFKAT, UDSAW etc. }\end{array}$ \\
\hline $\begin{array}{l}\text { Changes in tips \& gratuities practices. Will } \\
\text { employers ensure that all tips and gratuities are } \\
\text { paid to the employer? Impact on customer } \\
\text { behaviour? }\end{array}$ & $\begin{array}{l}\text { Sectoral studies of hospitality and hairdressing. Gather more } \\
\text { information on practices in conjunction with Inland Revenue? } \\
\text { NES data on occupational basis (waiters, bar staff, hairdressers, } \\
\text { taxi drivers). Union intelligence - GMB, CAB, and Low Pay } \\
\text { Unit. }\end{array}$ \\
\hline $\begin{array}{l}\text { Allowances and supplements. Will employers } \\
\text { consolidate allowances into basic pay (eg } \\
\text { London allowance)? }\end{array}$ & $\begin{array}{l}\text { Sectoral studies, plus IDS/IRS data on changes in patterns of } \\
\text { allowances (eg IDS London Weighting Study) - may need to } \\
\text { alert these pay monitoring organisations to the issues. }\end{array}$ \\
\hline $\begin{array}{l}\text { Benefits. Will employers withdraw benefits } \\
\text { from the low paid for NMW? How } \\
\text { hospitality/agric deal with accomm offset? }\end{array}$ & $\begin{array}{l}\text { Sectoral studies. Survey of employer practice via } \\
\text { employers/trade associations and unions? }\end{array}$ \\
\hline $\begin{array}{l}\text { Changes for those without contractual working } \\
\text { hours. Will homeworkers etc paid solely by } \\
\text { output be given working time contracts }\end{array}$ & LFS data. Sectoral studies. Survey of homeworkers? \\
\hline $\begin{array}{l}\text { Pay reference period. How employers deal with } \\
\text { the one month maximum? Treatment of bonuses } \\
\text { and annualised hours systems? }\end{array}$ & Sectoral studies plus LFS data on working patterns. \\
\hline $\begin{array}{l}\text { Pensions. Will employers seek to reduce } \\
\text { pension entitlement in low paid sectors? }\end{array}$ & Sectoral studies. DSS interest? \\
\hline
\end{tabular}

Source: Low Pay Commission NMW: Monitoring and Evaluation, 5 August 1998 


\section{References}

Bain, G. (1999) “The National Minimum Wage: Further Reflections”, Employee Relations, forthcoming.

Bank of England (1998a) Inflation Report, May.

Bank of England (1998b) "The National Minimum Wage and Other Labour Market Reforms", Quarterly Bulletin, August.

Beckett, M. (1998) Private Communication. 22 June.

Bickerstaffe, R (1998) “Decent Pay for All Please Tony”, The Independent, 17 September.

British Chamber of Commerce (1998). BCC Reacts to Minimum Wage. Press Release 25/98, 18 June.

British Hospitality Association (1998) Minimum Wage Decision is Realistic. Press Release, May 28.

Callaghan, Bill (1998) "The Future of Work: A Challenge of Partnership", Centrepiece, Vol.3, Issue 3, Autumn.

Cully M. and six others (1998) The 1998 Workplace Employment Relations Survey: The First Findings, DTI.

Department of Trade \& Industry (1998a) The National Minimum Wage: The Government's Evidence to the Low Pay Commission, January.

Department of Trade \& Industry (1998b) Draft National Minimum Wage Regulations, Employment Relations Directorate, URN 98/885, Sept.

Dickens, R. and Machin, S. (1998) “Minimum Wage: Maximum Impact?”, Centrepiece, Vol.3, Issue 3, Autumn, pp.10-13.

Dickens, R. and Machin, S. (1999) The Minimum Wage, Cambridge: MIT Press.

Dickens, R., Machin, S. and Manning, A. (1997) "Introducing a National Minimum Wage: Submission to LPC", mimeo Centre for Economic Performance, London School of Economics, October.

Dolado, J., Kramarz, F., Machin, S., Manning, A., Margolis, D. and Teulings, C. (1996) “The Economic Impact of Minimum Wages in Europe”, Economic Policy, Vol.23, pp.317-372.

Donovan, Lord (1968) Royal Communication on Trade Unions and Employers Associations, Report, Cmnd 3623, London: HMSO.

Fernie, S. and Metcalf, D. (1996) "Low Pay and Minimum Wages: The British Evidence", Special Report, Centre for Economic Performance, London School of Economics. 
Gosling, A. (1996) "Minimum Wages: Possible Effects on the Distribution of Income", Fiscal Studies, Vol.17(4), pp.31-48.

Income Data Services (1997) Pay Systems and Pay Structures and the Relationships to Low Pay, December.

Institute for Fiscal Studies (1998) "Effects of the minimum wage", 5 June, mimeo.

Low Pay Commission (1998) The National Minimum Wage, First Report of LPC, Cm 3976, London: Stationary Office.

Low Pay Unit (1998) "Minimum Wage Goes Down in History”, New Review, July/August.

Marginson, P. (1998) New Labour's Britain: Between Deregulation and Reregulation.

Thirteenth Foenander Lecture, 20 August, University of Melbourne.

McClements, L. (1997) "Equivalence Scales for Children”, Journal of Public Economics, Vol.8, pp.191-210.

Metcalf, D. (1981) Low Pay, Occupational Mobility and Minimum Wage Policy in Britain, Washington DC: American Enterprise Institute.

Metcalf, D. (1999) "The Low Pay Commission and the National Minimum Wage", Economic Journal, Vol.109, February.

Nickell, S., Narendranathan, W. and Metcalf, D. (1985) "An Investigation into the Incidence and Dynamic Structure of Sickness and Unemployment in Great Britain 1965-75", Journal of Royal Statistical Society, Vol.148(3).

OECD (1997) Minimum Wages in OECD Countries: Evidence to LPC, Paris.

OECD (1998) "Making the Most of the Minimum: Statutory Minimum Wages, Employment and Poverty", Employment Outlook, chapter 2.

Overell, S. (1998) "Getting on Famously: Interview with Stephanie Monk", People Management, 23 July.

Sachdev, S. and Wilkinson, F. (1998) “Minimal Impact?”, New Review, July/August.

Treasury (1998) "Employment Effects of the Minimum Wage", May, mimeo.

Turner, L. (1997) "Up Against the Fallen Wall: The Crisis of Social Partnership in Unified Germany" in L. Turner (ed) Negotiating the New Germany: Can Social Partnership Survive? Ithaca: ILR Press.

Wilkinson, D. (1998) "Towards Reconciliation of the NES and LFS Earnings Data", Labour Market Trends, May, pp.223-231. 